\title{
Allozymic variation and differentiation in the chilean blue mussel, Mytilus chilensis, along its natural distribution
}

\author{
Jorge E. Toro, Grace C. Castro, Johana A. Ojeda and Ana M. Vergara \\ Universidad Austral de Chile, Instituto de Biología Marina "Dr. Jürgen Winter”, Valdivia, Chile.
}

\begin{abstract}
Genetic differentiation in the Chilean blue mussel Mytilus chilensis (Hupé 1854) was investigated based on the variation in the allozyme frequencies of Pgm, Gpi, Icd, Me, Gsr, Lap and Pep in eight samples collected along $1800 \mathrm{~km}$ from Arauco (VIII Region) to Punta Arenas (XII Region). Despite the large geographic separations, values of Neis unbiased genetic distance, D (0.004-0.048) and standardised genetic variation among populations, Fst $(0.011-0.055)$ were small. The levels of gene flow $(\mathrm{Nm}=8)$ found in this study prevent the effect of differentiation among populations by genetic drift. This findings indicate that its long-lived planktotrophic larvae provides this species with considerable dispersal ability throughout its range which is favoured by the ocean currents along the chilean coast. In terms of management of the $M$. chilensis fishery, the results provide no evidence for discrete stocks, with the possible exception of the Punta Arenas population. Considering the intensive aquaculture activities with this species the present study provide preliminary data which can be used as a baseline for further characterization and /or monitoring these mussel populations.
\end{abstract}

Key words: allozyme, Mytilus chilensis, population genetics, gene flow, Chile.

Received: July 21, 2004; Accepted: May 31, 2005.

The Chilean blue mussel (Mytilus chilensis, Hupe 1854 ) is an economically important resource in southern Chile, commonly known as chorito or quilmahue. It is widely distributed on hard substrata in the lower intertidal zone to $25 \mathrm{~m}$ depths, along the chilean coast line (Brattström and Johanssen, 1983). The range of the species extends over $40^{\circ}$ of latitude from Arica to Cape Horn (Lancellotti and Vázquez, 2000) and it is impacted by a major oceanographic feature, the West Wind Drift $\left(43^{\circ} \mathrm{S}\right)$ that defines the boundary between the main current directions along the chilean Coast (Strub and Mesías, 1998). Winter et al. (1984), determined that there was an annual reproductive cycle, with spawning occurring during spring and summer. Toro and Sastre (1995) and Toro et al. (2004) have shown that M. chilensis possesses a planktotrophic larval stage with a pelagic existence of $45 \mathrm{~d}$. The species thus has the potential for long-distance dispersal over a scale of hundreds of kilometers along the chilean coast. Its culture began in 1943 in the Chiloé Island, southern Chile (Osorio et al., 1979) and the aquaculture production raised from 3,864 $\mathrm{t}$ in 1993 to 41,406 $\mathrm{t}$ in 2001. Despite this explosive development of $M$. chilensis aquaculture, population genetics studies in the chilean mussel (Mytilus chilensis) are scarce

Send correspondence to Jorge E. Toro. Universidad Austral de Chile, Instituto de Biología Marina"Dr. Jürgen Winter", Casilla 567. Valdivia, Chile. E-mail: jtoro@uach.cl. in the literature. Only a few studies with limited sampling are reported in the scientific literature mainly focused to dilucidate the distribution of the Mytilus edulis species complex (Koehn, 1991; McDonald et al., 1991).

An important question, from both evolutionary and fishery amangement perspectives, is the extent of gene flow and associated genetic differentiation among Mytilus chilensis populations at a macrogeographic (over $100 \mathrm{~km}$ ) scale. Marine species with longer larval phases are generally though to disperse further and have more gene flow, larger geographic ranges, lower levels of genetic differentiation among populations, and high levels of genetic variation within populations (Scheltema and Williams, 1983; Waples, 1987; Palumbi, 1995; Williams and Benzie, 1993). However, expected patterns of gene flow and population connectivity in Mytilus chilensis could be altered by oceanographic features peculiar to its range, such as the presence of the west wind drift (WWD) which bisects the flow of currents along the chilean coast (Strub and Mesías, 1998). Also, human mediated dispersal may have heavely affected the levels of genetic variation in several southern Chile stocks, because most of the mussel cultures used juveniles (seed) transferred from Yaldad Bay (Winter et al., 1984) that may caused in some locations the restocking of local natural populations with juveniles from the Yaldad population. 
In this paper we examine the genetic structure of Mytilus chilensis collected from eight widely separated (up to $1800 \mathrm{~km}$ ) sites along the chilean coast, using allozyme electrophoresis to establish the extend of gene flow and levels of genetic differentiation.

Samples of mussels were collected by dredging or by diving at eight localities extending over $1800 \mathrm{~km}$ along the chilean coast (covering the whole range of the species natural distribution) from Arauco (VIII Región) to Pta. Arenas (XII Región) (Figure 1). The mussels ( $\mathrm{N}=120$ from each population) were delivered alive to the laboratory where they were immediately dissected and isolated tissues were stored in liquid nitrogen for subsequent electrophoretic analysis.

Tissue samples from abductor muscle and hepatopancreas were homogenized in $50-100 \mu \mathrm{L}$ of $0.05 \mathrm{M}$ Tris$\mathrm{HCl}$ buffer, $\mathrm{pH}$ 8.0. Standard techniques of horizontal starch (12\%) gel electrophoresis were assayed in the following loci: PGM (2.7.5.1), GPI (5.3.1.9), LAP (3.4.11.1), EST (3.1.1.1), ODH (1.5.1.11), XDH (1.2.1.37), Alfa GPD (1.1.1.8), MDH (1.1.1.37), ME (1.1.1.40), AAT (2.6.1.1), PEP (3.4.11.13), IDH (1.1.1.42), ICD (1.1.1.2), MPI (5.3.1.8) y GSR (1.1.4.2). Starch gels were stained according to (Shaw and Prassad, 1970; Harris and Hopkinson, 1976; Selander et al., 1983; Beaumont and Toro, 1996). Alleles were designated alphabetically according to their migration relative to the most common electromorph. A locus was considered polymorphic if the frequency of the most common allele did not exceed 0.95 . Data were analysed using the computer programs POPGENE V. 1.31 (Yeh and Boyle, 1997) and GENETIX V 4.05.2. These programs were used to test for Hardy-Weinberg equilibrium, to provide F-statistics with their significance and Neis (Nei,

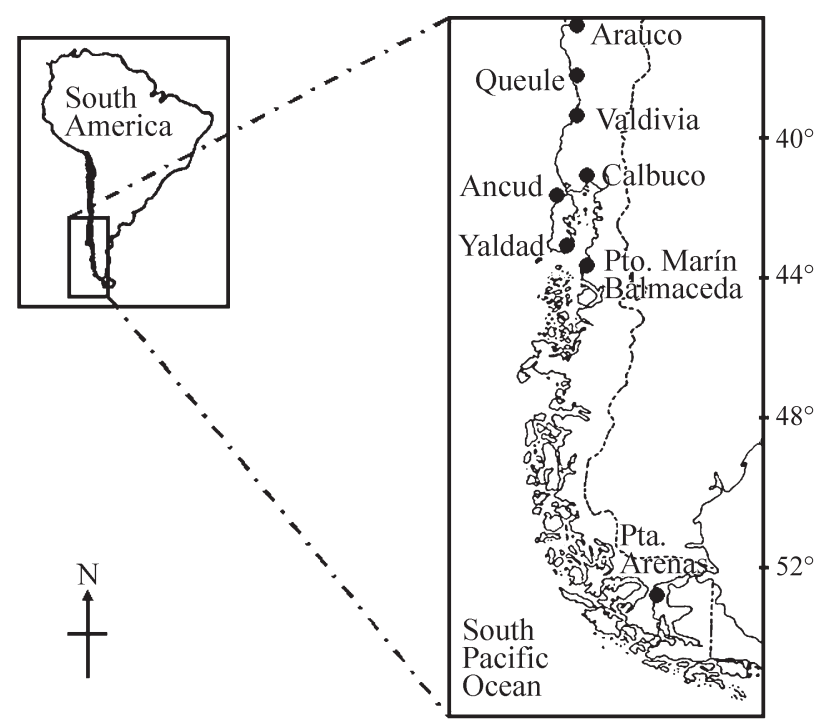

Figure 1 - Locations of the eight natural populations of the chilean blue mussel (Mytilus chilensis) sampled along its whole natural distribution in southern Chile $(\bullet)$.

1978) unbiased genetic distances (D) and identities (I). A UPGMA cluster analysis was performed using I values. The Mantel test using 50,000 randomisations was carried out for association between geographic distance and the genetic distance, using PopTools (Hood, 2004).

Only seven variable loci $(40.8 \%$ range $=33.3-46.7 \%)$ differing in gene frequencies were found across the geographic samples, Leucine aminopeptidase, glucose phosphate isomerase, Malic Enzime, Peptidase, Isocitrate Deshidrogenase, Glutatione reductase and phospho glucomutase. The allele frequencies for the seven polymorphic

Table 1 - Allele frequencies for the seven polymorphic loci screened in eight populations of the chilean blue mussel (Mytilus chilensis).

\begin{tabular}{|c|c|c|c|c|c|c|c|c|}
\hline Locus allele & Arauco & Queule & Valdivia & Calbuco & Ancud & Yaldad & Pto. M.B. & Pta. Arenas \\
\hline \multicolumn{9}{|l|}{ PGM } \\
\hline $\mathrm{n}$ & 109 & 108 & 116 & 110 & 99 & 128 & 99 & 100 \\
\hline A & 0.0275 & 0.0694 & 0.0603 & 0.0136 & 0.0101 & 0.0078 & 0.0051 & 0.2950 \\
\hline B & 0.7936 & 0.7454 & 0.7802 & 0.7864 & 0.8283 & 0.7969 & 0.8384 & 0.4650 \\
\hline $\mathrm{C}$ & 0.1786 & 0.1852 & 0.1595 & 0.2000 & 0.1616 & 0.1953 & 0.1566 & 0.2350 \\
\hline $\mathrm{D}$ & 0.0000 & 0.0000 & 0.0000 & 0.0000 & 0.0000 & 0.0000 & 0.0000 & 0.0050 \\
\hline \multicolumn{9}{|l|}{ GPI } \\
\hline $\mathrm{n}$ & 112 & 80 & 102 & 110 & 110 & 111 & 99 & 107 \\
\hline A & 0.1071 & 0.0312 & 0.0294 & 0.0955 & 0.0909 & 0.0721 & 0.1263 & 0.1262 \\
\hline B & 0.7277 & 0.8625 & 0.8775 & 0.8000 & 0.6636 & 0.8423 & 0.7727 & 0.5794 \\
\hline $\mathrm{C}$ & 0.1607 & 0.1062 & 0.0931 & 0.1045 & 0.2455 & 0.0856 & 0.1010 & 0.2944 \\
\hline $\mathrm{D}$ & 0.0045 & 0.0000 & 0.0000 & 0.0000 & 0.0000 & 0.0000 & 0.0000 & 0.0000 \\
\hline \multicolumn{9}{|l|}{ ICD } \\
\hline $\mathrm{n}$ & 112 & 108 & 115 & 110 & 110 & 141 & 99 & 107 \\
\hline A & 0.0268 & 0.0417 & 0.0087 & 0.0500 & 0.0227 & 0.0177 & 0.0253 & 0.0327 \\
\hline B & 0.9375 & 0.9444 & 0.9565 & 0.8773 & 0.9545 & 0.9645 & 0.9646 & 0.9252 \\
\hline $\mathrm{C}$ & 0.0357 & 0.0139 & 0.0348 & 0.0727 & 0.0227 & 0.0177 & 0.0101 & 0.0421 \\
\hline
\end{tabular}


Table 1 (cont.)

\begin{tabular}{|c|c|c|c|c|c|c|c|c|}
\hline Locus allele & Arauco & Queule & Valdivia & Calbuco & Ancud & Yaldad & Pto. M.B. & Pta. Arenas \\
\hline \multicolumn{9}{|l|}{$\mathrm{ME}$} \\
\hline $\mathrm{n}$ & 112 & 108 & 116 & 110 & 110 & 111 & 98 & 106 \\
\hline A & 0.0223 & 0.1852 & 0.1078 & 0.0227 & 0.0318 & 0.0721 & 0.0816 & 0.0377 \\
\hline B & 0.1652 & 0.2778 & 0.3233 & 0.2455 & 0.1864 & 0.2973 & 0.2959 & 0.2311 \\
\hline $\mathrm{C}$ & 0.4554 & 0.2454 & 0.2974 & 0.4182 & 0.3727 & 0.3874 & 0.2959 & 0.3962 \\
\hline $\mathrm{D}$ & 0.2857 & 0.1806 & 0.2112 & 0.2818 & 0.2364 & 0.2207 & 0.2500 & 0.2406 \\
\hline $\mathrm{E}$ & 0.0714 & 0.1111 & 0.0603 & 0.0318 & 0.1727 & 0.0225 & 0.0765 & 0.0943 \\
\hline \multicolumn{9}{|l|}{ GSR } \\
\hline $\mathrm{n}$ & 110 & 108 & 116 & 110 & 110 & 111 & 97 & 107 \\
\hline A & 0.0227 & 0.0000 & 0.0086 & 0.0364 & 0.0182 & 0.0450 & 0.0155 & 0.0514 \\
\hline B & 0.9409 & 0.9306 & 0.9181 & 0.9545 & 0.9812 & 0.9505 & 0.8969 & 0.8972 \\
\hline $\mathrm{C}$ & 0.0364 & 0.0694 & 0.0733 & 0.0091 & 0.0000 & 0.0450 & 0.0876 & 0.0514 \\
\hline \multicolumn{9}{|l|}{ LAP } \\
\hline $\mathrm{n}$ & 111 & 106 & 116 & 112 & 107 & 115 & 93 & 100 \\
\hline A & 0.2252 & 0.2736 & 0.2069 & 0.0938 & 0.1963 & 0.1565 & 0.2312 & 0.2600 \\
\hline B & 0.5090 & 0.5330 & 0.4784 & 0.4777 & 0.5234 & 0.5217 & 0.6720 & 0.4800 \\
\hline $\mathrm{C}$ & 0.2432 & 0.1887 & 0.2802 & 0.3438 & 0.2523 & 0.2783 & 0.0968 & 0.2400 \\
\hline $\mathrm{D}$ & 0.0225 & 0.0047 & 0.0345 & 0.0848 & 0.0280 & 0.0435 & 0.0000 & 0.0200 \\
\hline \multicolumn{9}{|l|}{ PEP } \\
\hline $\mathrm{n}$ & 111 & 108 & 107 & 112 & 80 & 136 & 96 & 101 \\
\hline A & 0.1486 & 0.4815 & 0.5047 & 0.3705 & 0.2313 & 0.4449 & 0.4583 & 0.3119 \\
\hline B & 0.3874 & 0.4398 & 0.3458 & 0.4062 & 0.4750 & 0.4338 & 0.4583 & 0.4208 \\
\hline $\mathrm{C}$ & 0.3604 & 0.0648 & 0.1262 & 0.1786 & 0.2938 & 0.1176 & 0.0833 & 0.1881 \\
\hline $\mathrm{D}$ & 0.1036 & 0.0139 & 0.0234 & 0.0446 & 0.0000 & 0.0037 & 0.0000 & 0.0792 \\
\hline
\end{tabular}

Key: [PGM: phosphoglucomutase; GPI: glucose phosphate isomerase; IDH: isocitrate dehydrogenase; ME: malic enzyme; GSR: glutathione reductase; LAP: leucine aminopeptidase; PEP: peptidase ]; $\mathrm{n}=$ number of specimins scored.

loci in each population analysed are shown in Table 1 . The ME locus was the most variable in all eight populations of Mytilus chilensis, followed by LAP and PEP (Table 1). The same common allele at the ICD and GSR loci were the most frequent in all populations, with two other alleles present at lower frequencies. Three alleles were present for PGM and GPI loci, with one allele predominant in all populations, a fourth rare allele was found for PGM in Pta. Arenas and for GPI in Arauco (Table 1).

Mean number of alleles per locus ranged from 3.28 to 3.71 among the eight populations of $M$. chilensis. Mean heterozygosities for the populations ranged from 25.0 to 32.0 (Table 2) with a generalized heterozygote deficiency in all loci in Hardy-Weinberg disequilibrium (Table 2). Genetic distances, $\mathrm{D}$, among eight populations of $M$. chilensis were on the whole small, ranging from 0.003 to 0.048 (Figure 2). A Mantel test using 50,000 randomisations showed evidence for a significant correlation $(\mathrm{p}<0.05)$ between genetic and geographic (coastal) distance (with and without the the inclusion of Punta Arenas population).

The standarized variance of gene frequencies that measures the fractional reduction in heterozygosity relative to random mating was small $(\mathrm{Fst}=0.0303, \mathrm{p}<0.05)$. In fact, only $3.0 \%$ of the variance in gene frequency was atributable to among-population variation whereas most differences found within populations. The estimates of the individual reduction in heterozygosity relative to its population indicate an excess of homozygotes (Fis $=0.29$, $\mathrm{p}<0.05$ ), observed at many loci across all populations (Table 2). The migration rate deduced from the Fst value suggested a theorical exchange of $\mathrm{Nm}=8$ individuals per generation between pair of samples.

A cluster analysis based on the unweighted pair group method and Neis co-efficient of unbiased genetic identity (Nei, 1978) showed that all populations were genetically quite similar, with the Pta. Arenas population most distinct (Figure 2).

A hight genetic (allozymic) variation has been reported in marine organisms (Ayala et al., 1973; Levington, 1975; Koehn et al., 1976). The $40.8 \%$ polymorphism reported here is within the range reported for other marine invertebrates (Nevo et al., 1984). The mean heterozygosity level in M. chilensis (29.7\%) is within the range of variation reported for other bivalves (Buroker et al., 1979a, 1979b; McDonald et al., 1991; Toro and Vergara, 1995).

Heterozygote deficiency has been widely reported in marine invertebrates (Zouros and Foltz, 1984; Mallet et al., 1985; Gaffney et al., 1990; Beaumont, 1991; Toro and 
Table 2 - Genetic variability measures for eight populations of Mytilus chilensis

\begin{tabular}{|c|c|c|c|c|c|c|c|c|}
\hline \multirow[b]{2}{*}{ Locus } & \multicolumn{4}{|c|}{ Arauco } & \multicolumn{4}{|c|}{ Queule } \\
\hline & Но & $\mathrm{He}$ & $\mathrm{Hd}$ & & Но & $\mathrm{He}$ & $\mathrm{Hd}$ & \\
\hline PGM & 0.33 & 0.33 & 0.00 & ns & 0.36 & 0.40 & -0.10 & $*$ \\
\hline GPI & 0.38 & 0.43 & -0.11 & $\mathrm{a}$ & 0.25 & 0.24 & 0.04 & ns \\
\hline ICD & 0.03 & 0.11 & -0.72 & $*$ & 0.03 & 0.10 & -0.70 & $*$ \\
\hline $\mathrm{ME}$ & 0.18 & 0.31 & -0.41 & $*$ & 0.70 & 0.78 & -0.10 & $*$ \\
\hline GSR & 0.10 & 0.11 & 0.00 & ns & 0.10 & 0.12 & -0.16 & $*$ \\
\hline LAP & 0.49 & 0.63 & -0.22 & $*$ & 0.50 & 0.60 & -0.17 & $*$ \\
\hline PEP & 0.54 & 0.68 & -0.20 & $*$ & 0.29 & 0.57 & -0.49 & $*$ \\
\hline \multirow[t]{2}{*}{ Means } & 0.29 & 0.37 & -0.30 & & 0.32 & 0.4 & -0.20 & \\
\hline & \multicolumn{4}{|c|}{ Valdivia } & \multicolumn{4}{|c|}{ Calbuco } \\
\hline Locus & Но & $\mathrm{He}$ & $\mathrm{Hd}$ & & Но & $\mathrm{He}$ & $\mathrm{Hd}$ & \\
\hline PGM & 0.28 & 0.36 & -0.22 & $*$ & 0.28 & 0.34 & -0.17 & $\mathrm{a}$ \\
\hline GPI & 0.16 & 0.22 & -0.27 & $*$ & 0.34 & 0.34 & 0.00 & ns \\
\hline ICD & 0.00 & 0.08 & -1.00 & $*$ & 0.02 & 0.22 & -0.90 & $*$ \\
\hline ME & 0.62 & 0.74 & -0.16 & $*$ & 0.34 & 0.68 & -0.50 & $*$ \\
\hline GSR & 0.14 & 0.15 & -0.06 & ns & 0.05 & 0.08 & -0.37 & $*$ \\
\hline LAP & 0.53 & 0.64 & -0.17 & $*$ & 0.57 & 0.63 & -0.09 & $*$ \\
\hline PEP & 0.42 & 0.60 & -0.30 & $*$ & 0.50 & 0.66 & -0.24 & $*$ \\
\hline \multirow[t]{2}{*}{ Means } & 0.31 & 0.4 & -0.22 & & 0.30 & 0.42 & -0.28 & \\
\hline & \multicolumn{4}{|c|}{ Ancud } & \multicolumn{4}{|c|}{ Yaldad } \\
\hline Locus & Ho & $\mathrm{He}$ & Hd & & Ho & $\mathrm{He}$ & Hd & \\
\hline PGM & 0.34 & 0.28 & 0.21 & $\mathrm{a}$ & 0.32 & 0.32 & 0.00 & ns \\
\hline GPI & 0.44 & 0.49 & -0.10 & $*$ & 0.29 & 0.27 & 0.07 & $\mathrm{a}$ \\
\hline ICD & 0.01 & 0.08 & -0.87 & $*$ & 0.05 & 0.06 & -0.16 & $*$ \\
\hline ME & 0.40 & 0.73 & -0.45 & $*$ & 0.35 & 0.70 & -0.50 & $*$ \\
\hline GSR & 0.01 & 0.03 & -0.66 & $*$ & 0.08 & 0.09 & -0.11 & ns \\
\hline LAP & 0.56 & 0.62 & -0.09 & $*$ & 0.42 & 0.62 & -0.32 & $*$ \\
\hline PEP & 0.46 & 0.63 & -0.26 & $*$ & 0.33 & 0.60 & -0.45 & $*$ \\
\hline \multirow[t]{2}{*}{ Means } & 0.32 & 0.41 & -0.21 & & 0.26 & 0.38 & -0.31 & \\
\hline & \multicolumn{4}{|c|}{ Pto. M. Balmaceda } & \multicolumn{4}{|c|}{ PTA. Arenas } \\
\hline Locus & Ho & $\mathrm{He}$ & $\mathrm{Hd}$ & & Ho & $\mathrm{He}$ & $\mathrm{Hd}$ & \\
\hline PGM & 0.24 & 0.27 & -0.11 & ns & 0.18 & 0.64 & -0.71 & $*$ \\
\hline GPI & 0.36 & 0.37 & -0.02 & ns & 0.47 & 0.56 & -0.16 & $*$ \\
\hline ICD & 0.01 & 0.06 & -0.83 & $*$ & 0.01 & 0.14 & -0.92 & $*$ \\
\hline $\mathrm{ME}$ & 0.58 & 0.74 & -0.21 & $*$ & 0.43 & 0.72 & -0.40 & $*$ \\
\hline GSR & 0.02 & 0.18 & -0.75 & $*$ & 0.07 & 0.18 & -0.61 & $*$ \\
\hline LAP & 0.20 & 0.48 & -0.58 & $*$ & 0.41 & 0.64 & -0.35 & $*$ \\
\hline PEP & 0.35 & 0.57 & -0.38 & $*$ & 0.52 & 0.68 & -0.23 & $*$ \\
\hline Means & 0.25 & 0.38 & -0.34 & & 0.30 & 0.51 & -0.41 & \\
\hline
\end{tabular}

Key: Ho = observed heterozygosity (direct count); He +expected heterozygosity; Hd, degree of departure of genotypic frequencies from HardyWeinberg expectations where $\mathrm{Hd}=(\mathrm{Ho}-\mathrm{He}) / \mathrm{He}$ (Selander, 1970).

[PGM: phosphoglucomutase; GPI: glucose phosphate isomerase; IDH: isocitrate dehydrogenase; ME: malic enzyme; GSR: glutathione reductase; LAP: leucine aminopeptidase; PEP: peptidase ].

*: Significant deviation from expected at $\mathrm{p}<0.05$. ns: Non significant. a : No test possible, less mussels than expected for one genotypic class.

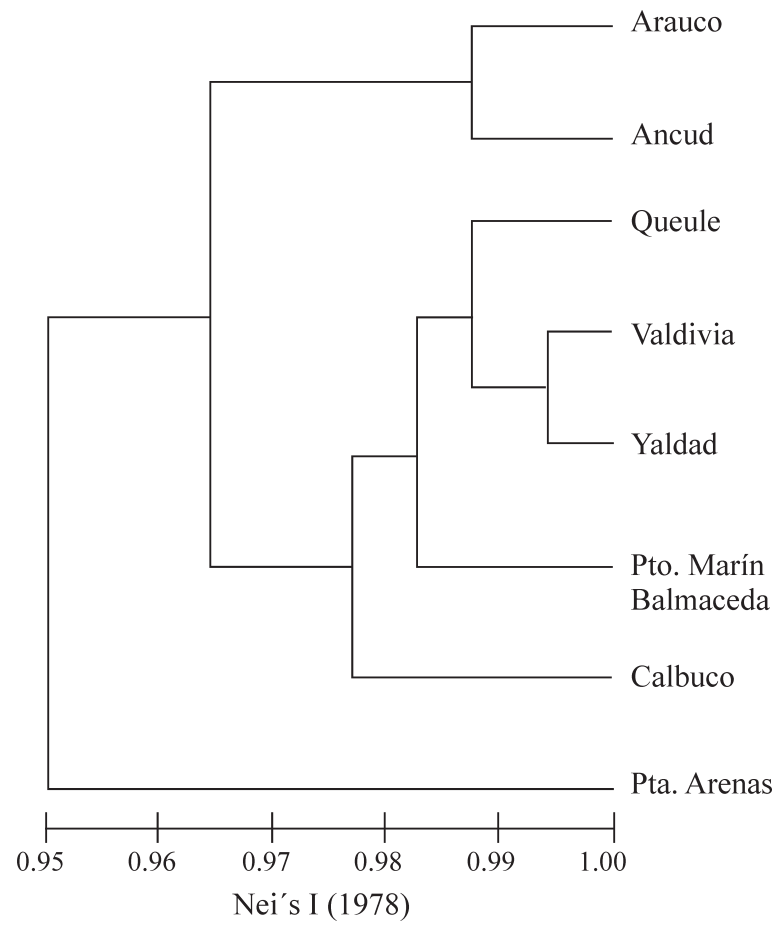

Figure 2 - A phenetic dendrogram showing the relationship of eight populations of the chilean blue mussel (Mytilus chilensis), based on seven polymorphic loci.

Vergara, 1995). Significant heterozygote deficiency was also found in this study, and corroborate by the positive Fis $(0.29, \mathrm{P})$ which indicates and excess of homozygous animals within each population. There are several possible explanations (relatively high levels of inbreeding, null alleles, aneuploidy, molecular imprinting, selection, Wahlund effect) which have been discussed extensively elsewhere (Fujio et al., 1983; Zouros and Foltz, 1984; Mallet et al., 1985; Gaffney et al., 1990; Beaumont, 1991; Toro and Vergara, 1995). No one of these seems either sufficient or plausible alone for $M$. chilensis, and the overall deficit probably results from several small effects, all tending to reduce heterozygosity, which add to a significant overall deficit. Nevertheless, the causal mechanism of the heterozygote deficiency reported here remain to be studied.

Very low genetic diffentiation was found among eight populations of $M$. chilensis sampled over distances greater than $1800 \mathrm{~km}$ along the Chilean coastline $(\mathrm{D}=0.003-0.048, \mathrm{Fst}=0.01-0.05)$. This indicate high levels of gene flow and suggests that these populations act as a single interbreeding population. However, one population sampled in the Magellanican Channel, Pta. Arenas, was genetically distinct from the others, although the scale of differentiation was not large $(\mathrm{D}=0.032-0.048)$. This differentiation, even low could be the result of the West Wind Drift (WWD) and the Cape Horn Current (Strub and Mesías, 1998) which precludes the larval transport towards the northern mussel populations. A Mantel test excluding the Punta Arenas population gave a significan correlation 
value $(\mathrm{r}=0.113, \mathrm{p}<0.05)$, indicating more evidence of an isolation by distance scenario.

Theory predicts that a global value of $\mathrm{Nm}>1$ prevents random differentiation by genetic drift (Slakin, 1987). Thus the migration rate reported here $(\mathrm{Nm}=8)$ suggest that some deterministic factors are involved in the among population differentiation of $M$. chilensis. Our results seems to indicate that the long lived (45 d) larvae of $M$. chilensis provide the species with considerable dispersal ability throughout its range, and that this dispersal is not affected but enhanced by oceanographic features such as the WWD and several coastal currents along the Chilean coastline (Strub and Mesías, 1998; Camus, 2001). Indeed, the very low genetic differentiation between such populations as Valdivia and Yaldad, Queule and Yaldad, Ancud and Arauco (Figure 2) suggests that larval transport along the coast does take place, perhaps in stepping-stone fashion, with each generation of larvae dispersing short distances along the coast, especially under the $45^{\circ} \mathrm{S}$ tending to homogenize the populations with the exception of the one from Pta. Arenas.

Interpopulational genetic homogenity has been described for other marine invertebrates along the Chilean coastline (Gallardo and Carrasco, 1996; Toro and Aguila 1996; Gallardo et al., 1998). Even when the results from the present study are consistent with the life-history features of the chilean blue mussel with a very prolonged larval life span (40-45 d) suggesting a potential for genetic homogenization over large geographical distances, we must keep in mind that this is a farming species, so there is a lot of gene flow through "seed" transplantation and restocking of juveniles (human activity), especially from Yaldad Bay, which is the main natural source of juveniles for culturing purposes (Winter et al., 1984) to other localities in southern Chile.

In terms of management of the M. chilensis fishery, our results provided no evidence for discrete stocks with the possible exception of the Pta. Arenas population. Management practices for this species thus can be independent of macrogeography, and they should be focused on a smaller spacial scale, dealing with differentiation of populations caused by environmental factors. Finally, our survey for natural populations of $M$. chilensis along the coastline of Chile gave as a result that the natural distribution of this species described by Lancellotti and Vásquez (2000) is actually highly reduced at its northern border from the $18^{\circ} \mathrm{S}$ to $35^{\circ} \mathrm{S}$. Further sampling will be carried out within the same localities to evaluate and/or monitoring the genetic variation of these populations, using PCR based DNA markers (RAPDs).

\section{Acknowledgments}

This work was supported by FONDECYT Grant 1050341 .

\section{References}

Ayala FJ, Hedgehock D, Zumwalt GS and Valentine W (1973) Genetic variation in Tridacna maxima, an ecological analog of some unseccessful evolutionary lineages. Evolution 27:177-191.

Beaumont AR (1991) Genetics studies of laboratory reared mussels, Mytilus edulis: Heterozygote deficiencies, heterozygosity and growth. Biol J Linn Soc 44:273-285.

Beaumont AR and Toro JE (1996) Allozyme genetics of Mytilus edulis subjected to copper and nutritive stress. J Mar Biol Assoc UK 76:1061-1071.

Brattström H and Johanssen A (1983) Ecological and regional zoogeography of the marine benthic fauna of Chile. Sarcia 68:289-339.

Buroker NE, Hershberger WK and Chew KK (1979a) Population genetics of the Family Ostreidae, I, Intraespecific studies of Crassostrea gigas and Saccostrea commercialis. Mar Biol 54:157-169.

Buroker NE, Hershberger WK and Chew KK (1979b) Population genetics of the family Ostreidae, II, Interespecific studies of the genera Crassostrea and Saccostrea. Mar Biol 54:171184.

Camus PA (2001) Marine biogeography of continental Chile. Rev Chil Hist Nat 74:587-617.

Fujio Y, Yamanaka R and Smith PJ (1983) Genetic variation in marine mollusks. Bulletin of the Japonese Society of Scientific Fisheries 49:1809-1817.

Gaffney PM, Scott TM, Kohen RK and Diehl WJ (1990) Interrelationships of heterozygosity, growth rate and heteozygote deficiencies in the Coot Clam, Mulinia lateralis. Genetics 124:687-699.

Gallardo M and Carrasco J (1996) Genetic cohesiveness among population of Concholepas concholepas (Gastropoda, Muricidae) in southern Chile. J Exp Mar Biol Ecol 197:237-249.

Gallardo M, Peñaloza L and Clasing E (1998) Gene flow and allozymic population structure in the clam Venus antiqua (King \& Broderip), (Bivalvia, Veneriidae) from southern Chile. J Exp Mar Biol Ecol 230:193-205.

Harris H and Hopkinson DA (1976) Handbook of Enzyme Electrophoresis in Human Genetics. North Holland Publ. Co., Amsterdam, 283 pp.

Hood GM (2004) PopTools version 2.6.2., Available on the internet URL http://www.cse.csire.au/poptools.

Koehn RK (1991) The genetics and taxonomy of species in the genus Mytilus. Aquaculture 94:125-145.

Koehn RK, Milkman R and Mitton J (1976) Population genetics of marine pelecypods, IV, Selection, migration and genetic differentiation in the blue mussel Mytilus edulis. Evolution 30:2-32.

Lancellotti DA and Vásquez JA (2000) Zoogeografía de macroinvertebrados bentónicos de la costa de Chile: Contribución para la conservación marina. Rev Chil Hist Nat 73:99-129.

Levington JS (1975) Levels of genetic polymorphism at two enzyme encoding loci in eight species of the genus Macoma (Mollusca, Bivalvia). Mar Biol 33:41-47.

McDonald JH, Seed R and Koehn RK (1991) Allozymes and morphometric characters of three species of Mytilus in the northern and southern hemispheres. Mar Biol 111:323-333.

Mallet AL, Zouros E, Gartner-Kepkay E, Freeman KR and Dickie LM (1985) Larval viability and heterozygote deficiency in 
populations of marine bivalves: Evidence from pair matings of mussels. Mar Biol 87:165-172.

Nei M (1978) Estimation of average heterozygosity and genetic distance from a small number of individuals. Genetics 89:583-590.

Nevo E, Beiles A and Ben-Shlomo R (1984) The evolutionary significance of genetic diversity: Ecological, demographic and life history correlates. In: Mani GS (ed) Lecture Notes in Biomathematics, v. 53, Evolutionary Dinamics of Genetic Diversity. Springer Verlag, Berlin, pp 13-213.

Osorio C, Atria J and Mann S (1979) Moluscos marinos de importancia económica en Chile. Biol Pesqu Chile 11:3-47.

Palumbi SR (1995) Using genetics as an indirect estimator of larval dispersal. In: McEdwards L (ed) Ecology of Marine Invertebrate Larvae. CRC Press Inc, Boca Raton, pp 369-387.

Scheltema RS and Williams IP (1983) Long distance dispersal of planktonic larvae and the biogeography and evolution of some polynesian and western pacific mollusks. B Mar Sci 33:545-565.

Selander RK, Smith MH, Yang SY, Johnson WE and Gentry JB (1971) Biochemical Polymorphism and Systematics in the Genus Perumyscus, I. Variation in the Old-Field Mause (Peromyscus polionotus), Studies in Genetics VI. University of Texas Publication n. 7103. Stud Genet 6:49-90.

Shaw CR and Prassad R (1970) Starch gel electrophoresis of enzymes - A compilation of recipes. Biochem Genet 4:297320.

Slakin M (1987) Gene flow and the geographic structure of natural populations. Science 236:287-292.

Strub PT and Mesías JM (1998) Coastal ocean circulation off western South America. In: Robinson AR and Brink KH (eds) The Sea, v 11, John Wiley \& Sons, New York, pp 273-313.
Toro JE and Vergara AM (1995) Evidence for selection against heterozygotes: Post-settlement excess of allozyme homozygosity in a cohort of the chilean oyster, Ostrea chilensis Philippi, 1845. Biol Bull 188:117-119.

Toro JE and Sastre D (1995) Induced triploidy in the Chilean blue mussel, Mytilus chilensis (Hupe 1854), and performance of triploid larvae. J Shellfish Res 14:161-164.

Toro JE and Aguila PR (1996) Genetic differentiation of populations of the oyster Ostrea chilensis in southern Chile. Aquat Living Resour 9:75-78.

Toro JE, Alcapán AC, Vergara AM and Ojeda JA (2004) Heritability estimates of larval and spat shell height in the Chilean blue mussel (Mytilus chilensis Hupe 1854) produced under controlled laboratory conditions. Aquac Res 35:5661.

Waples RS (1987) A multispecies approach to the análisis of gene flow in marine shore fishes. Evolution 41:385-400.

Williams ST and Benzie JAH (1993) Genetic consequences of long larval life in the starfish Linckia laevigata (Echinodermata, Asteroidea) on the Great Barrier Reef. Mar Biol 117:71-77.

Winter JE, Toro JE, Navarro JM, Valenzuela GS and Chaparro OR (1984) Recent developments, status and prospects of molluscan aquaculture on the Pacific coast of South America. Aquaculture 39:95-134.

Yeh FC and Boyle TJB (1997) Population genetic analysis of co-dominant and dominant markers and quantitative traits. Belg J Bot 129:157.

Zouros E and Foltz DF (1984) Minimal selection requirements for the correlation between heterozygosity and growth and for the deficiency of heterozygotes, in oyster populations. Dev Genet 4:393-405.

Associate Editor: João S. Morgante 